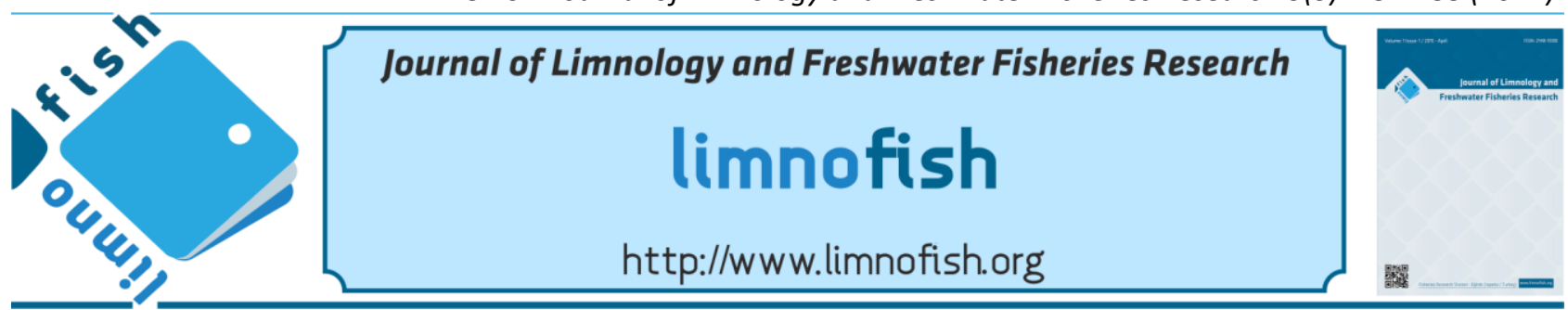

\title{
First Observation of European eel (Anguilla anguilla) As a Prey for Mallard (Anas platyrhynchos) in Gediz Delta Ramsar Area (Izmir Turkey)
}

\author{
Alp SALMAN \\ Ege University, Faculty of Fisheries, Department of Basic Sciences, 35100, Bornova, İzmir, Turkey
}

\section{A B STRACT}

In this study, a European eel (Anguilla anguilla L. 1758) was found in stomach content of a drake mallard (Anas platyrhynchos L. 1758) in Gediz Delta Ramsar Area (Izmir, Turkey) in spite of there is no fish in the diet of dabbling ducks. With this new record for Turkey, European eel would be added to the prey list of mallard as a new species.

Keywords: Anguilla anguilla, Anas platyrhynchos, prey, predator, stomach content

\section{ARTICLE INFO}

\section{CASE REPORT}

$\begin{array}{lll}\text { Received } & \text { :29.06.2017 } \\ \text { Revised } & : 24.08 .2017 \\ \text { Accepted } & : 19.10 .2017 \\ \text { Published } & : 29.12 .2017\end{array}$

DOI: $10.17216 /$ LimnoFish.324047

* CORRESPONDING AUTHOR

alp.salman@ege.edu.tr

Tel : +905425151792

Avrupa yılan balığı (Anguilla anguilla) nın Gediz deltası Ramsar alanında (İzmir Türkiye) Yeşilbaş ördek (Anas platyrhynchos) midesinde rastlanması

Öz: Yüzücü ördeklerin genellikle balık yeme özellikleri olmamakla birlikte bu grup ördeklerden en büyüklerinden biri olan ve Gediz deltası Ramsar alanı civarında avlanan bir yeşilbaş ördeğin (Anas platyrhynchos L.1758) mide içeriğinde tatlısu yılan balığına (Anguilla anguilla L.1758) rastlanmış olup, Türkiye'de gerek ördeğin besin diyetinde gerekse de yılan balığının tatlısulardaki predatörleri listesine yeni bir tür eklenmiş olmaktadır.

Anahtar kelimeler: Anguilla anguilla, Anas platyrhynchos, av, predatör, mide içeriği

How to Cite

Salman A. 2017. First Observation of European eel (Anguilla anguilla) As a Prey for Mallard (Anas platyrhynchos) in Gediz Delta Ramsar Area (İzmir Turkey) 3(3):187-188. doi: 10.17216/LimnoFish.324047

\section{Introduction}

Anguilla anguilla has been shown to be distributed from North Cape in Northern Norway, southwards along the coast of Europe, all coasts of the Mediterranean and on the North African Coast (Tesch 2003).

Aves species like herons (Ardea cinerea), cormorant (Phalarocorax carbo) and common merganser (Mergus merganser) are known to be predators of eels (Hastie et al. 2008). Although there were small fish in the diet of diving ducks, feeding of mallard (Anas platyrhynchos) which is one of the biggest sized dabbling ducks (nearly $60-63 \mathrm{~cm}$ ), is omnivorous type (Hocaoğlu 1992). It was reported that the feeding of nurturing ducks consists of $30 \%$ carnivorous $70 \%$ herbivorous and vice versa while in spawning period (Krapu and Reinecke 1992). The diet of omnivorous mallards consists of gastropods, crustaceans, worms, and insects (flies, Lepidoptera, dragonflies) and also small fishes (del Hoyo et al.1992; Snow and Perrins 1998) from animals. As plant materials seeds, thin roots from plants and the vegetative parts of aquatic and terrestrial plants (Swanson et al. 1985; Hocaoğlu 1992; Snow and Perrins 1998).

\section{Case}

Semelparous fish species A. anguilla has been added to the list of critically endangered fish species by IUCN, migrates between sea and freshwaters for reproduction purpose. The specimen (A. anguilla) which is the scope of this study, was found in 
December $31^{\text {st }}, 2016$, from the stomach content of a drake mallard which was hunted in Gediz Delta Ramsar Area (Izmir, Turkey). The specimen was found partly digested with no head, no body part from the mid-point of coelomic cavity. The length of ruptured eel that partly digested in the mallard stomach was $16 \mathrm{~cm}$. It was predicted that the eel was juvenile and its estimated length was $22-25 \mathrm{~cm}$ (Figure 1).

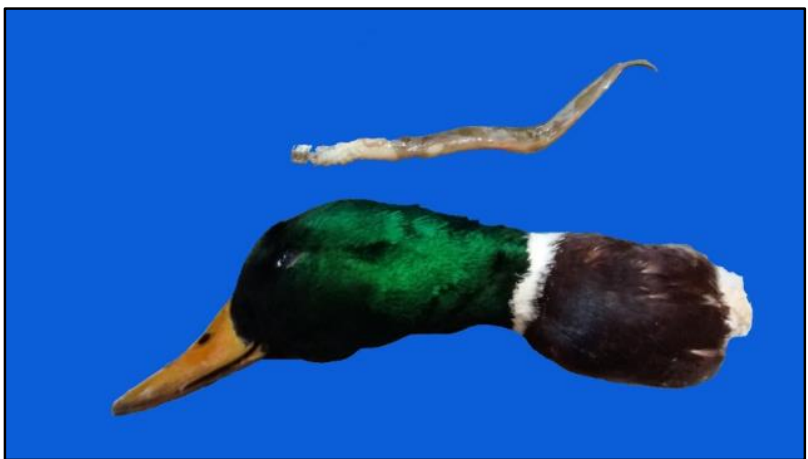

Figure 1. The European eel which was found in stomach from drake mallard (Same scale).

\section{Discussion}

The eel extracted from the stomach of mallard which is known as omnivorous and opportunistic (del Hoyo et al. 1992; Snow and Perrins 1998) was quite large in size (Figure 1) compared with sizes of foods in its normal diet (Krapu and Reinecke 1992; Hocaoğlu 1992).

So far, mallard has not been in the predator list of
European eel A. anguilla. Also, for the first time, eel has been reported in the prey list of mallard which is known as an opportunistic animal and rarely prey with small fish (Swanson et al. 1985; del Hoyo et al. 1992; Snow and Perrins 1998).

\section{References}

del Hoyo J, Elliott A, Sargatal J. 1992. Handbook of the birds of the world, Vol 1: Ostrich to ducks. Barcelona:Lynx Edicions 696 p.

Krapu, GL, Reinecke KJ. 1992. Foraging ecology and nutrition. In: Batt BDJ, Afton AD, Anderson MG, Ankney CD, Johnson DH, Kadlec JA, Krapu, GL, editors. Ecology and management of breeding waterfowl. Minneapolis: University of Minnesota Press. p. 1-30.

Hastie L, Hudson A, Laughton R, Shearer W. 2008. The status of the European eel (Anguilla anguilla) in watercourses of the Cairngorms National Park. Spey Research Trust. $21 \mathrm{p}$.

Hocaoğlu ÖL. 1992. Av Kuşlarımız. Ankara:Orman Bakanlığı Yayın Dairesi Başkanlığı 208 p. [in Turkish]

Snow DW, Perrins CM. 1998. The birds of the Western Palaearctic. Concise edition. Vol. 1 and 2. New York:Oxford University Press 1694 p.

Swanson GA, Meyer MI, Adomaitis VA. 1985. Foods consumed by breeding mallards on wetlands of southcentral North Dakota. J Wildlife Manage. 49(1):197203. doi: $10.2307 / 3801871$

Tesch FW. 2003. The eel, $3^{\text {th }}$ ed. Bodmin:Blackwell Science 408 p. 